\title{
SEASONAL STUDIES OF PHYSICO-CHEMICAL PARAMETERS AND WATER QUALITY ASSESMENT OF RIVER DHAMOLA USING WATER QUALITY INDEX
}

\author{
Dinkar Malik ${ }^{1 *}$ \\ *1 Department of Chemistry, M. S. College, Saharanpur U.P. 1800/1, Mission Compound, \\ Saharanpur-247001 (U.P)
}

*Corresponding Author: -

Email-dinkar_malik@rediffmail.com

\begin{abstract}
: -
River Dhamola, an important river of Saharanpur flowing through the districts of Western Uttar Pradesh, is subjected to varying degree of pollution caused by numerous untreated and/or partially treated waste inputs of municipal and industrial effluents. The present study has been carried out with the objective to examine variation in water quality characteristics within the river system, and to establish water quality-quantity relationships to provide a proper basis for establishing water quality objectives by collecting water sample from three different locations of the river and their WQI was determined from various physico-chemical parameters during rainy, winter and summer seasons. It is found that this water body is not suitable for drinking and irrigation purpose, so possible remedial methods should be adopted for this water resource for improving its quality. In this study Water quality Index was determined on the basis of various physicochemical parameters like $\mathrm{pH}$, temperature, turbidity, color, TDS, calcium hardness, total hardness, alkalinity, total suspended solid, magnesium hardness, chloride, DO and BOD.
\end{abstract}

Key words: Water Pollution, Total Dissolved Solids, Physico-Chemical Parameters, Alkalinity, Dhamola River. 


\section{INTRODUCTION}

Saharanpur is the gateway city of Uttar Pradesh in its extreme west. Due to ever increasing population, water demand is also increasing. To meet increasing demand, more water is extracted through tube wells because entire water supply is tube-well based. Water table is decreasing on account of more water extraction. To keep water table replenished, measures of ground water recharge by rainwater harvesting have to be made mandatory. The Dhamola River is one of the important rivers in western Uttar Pradesh (India). As the river passes through Saharanpur its water turns brownish and blackish as small scale industrial effluents, house hold and municipal wastes are discharged in it. River Dhamola continues up to Tapri and thereafter it merge into Hindon River. However, now the water quality of the river Dhamola has been drastically deteriorated due to discharge of industrial/domestic sewage and application of chemicals/pesticides in agriculture during past years. Human activities that involve urbanization, agricultural development, over use of fertilizers, inadequate management of land use and sewage disposal have directly or indirectly affected the quality of water and making it unfit for domestic purpose. Agriculture is also responsible for degrading the river water quality by generating runoff from animal husbandry units, which contain predominantly organic compounds from the use of mineral fertilizers and chemical pesticides (Jenkins et al., 1995; Collins and Jenkins, 1996). The pollution problems in industrial areas are significant. In particular, the water quality around Saharanpur city is so poor that water from the surrounding rivers can no longer be considered as a source of water supply for human consumptions (Agarwal et. al. 2011, Kumar et. al. 2004, APHA 1989, ISI 1983, WHO 1984, Malik 2015). The assimilation of waste water treatment mechanism is essential to have a sustainable environment (Shivaraju 2011). Water quality index (WQI) is a means to summarize large amounts of water quality data into simple terms for reporting to management and the public in a consistent manner. It tells us whether the overall quality of water bodies poses a potential threat to various uses of water. The WQI was first developed by Horton in the early 1970s, is basically a mathematical means of calculating a single value from multiple test results. For the evaluation of water quality, WQI was applied to river water (Singh, 1992; Naik and Purohit, 2001; Sharma et al., 2009; Gupta et al., 2012). In the present study Water quality Index was determined on the basis of various physico-chemical parameters like $\mathrm{pH}$, temperature, turbidity, color, TDS, calcium hardness, total hardness, alkalinity, total suspended solid, magnesium hardness, chloride, DO and BOD.

Table I - Sampling Station in Dhamola River

\begin{tabular}{|l|l|l|}
\hline $\begin{array}{l}\text { Sampling } \\
\text { Site Number }\end{array}$ & $\begin{array}{l}\text { Location of } \\
\text { sampling Sites }\end{array}$ & Description \\
\hline I & Muzaffrabad & $\begin{array}{l}\text { Agricultural runoff sources, Detergents and Domestic } \\
\text { waste sources and Animal wash, }\end{array}$ \\
\hline II & Rakesh Cinema & $\begin{array}{l}\text { Municipality wastes, Car and Animal wash, Soaps, } \\
\text { Detergents and Domestic waste sources }\end{array}$ \\
\hline III & Tapri & $\begin{array}{l}\text { Municipality wastes, Industrial Waste, Waste from paper } \\
\text { mill, Soaps, Detergents and Domestic waste sources }\end{array}$ \\
\hline
\end{tabular}

\section{Methodology: \\ Sampling Area:}

The water samples from the water body were taken in morning hours from 7.00 AM to 10.00 AM from three sampling sites and analyzed for 13 parameters by following the established procedure. The $\mathrm{pH}$, dissolved oxygen and turbidity were measured and estimated at sampling sites. The other parameters were measured in laboratory by the procedure given by APHA in the laboratory.

In this study for the calculation of Water Quality Index (WQI), 13 important parameters were chosen for physio-chemical analysis. WQI is one of the most effective ways to communicate information on water quality trends to policy makers, to shape sound public policy and implement the water quality improvement programmes efficiently (Tiwari and Mishra 1985). The weighted arithmetic index method (Brown et. al.) has been used for the calculation of Water Quality Index of water body. Quality rating $\mathrm{q}_{\mathrm{n}}$ was calculated by using the formula:

$\mathrm{q}_{\mathrm{n}}($ water quality rating $)=100(\mathrm{Vn}-\mathrm{Vio}) /(\mathrm{Sn}-\mathrm{Vio})$

where, $\mathrm{q}_{\mathrm{n}}=$ Quality rating for the $\mathrm{n}^{\text {th }}$ Water Quality parameter

$\mathrm{V}_{\mathrm{n}}=$ Estimated value of the $\mathrm{n}^{\text {th }}$ parameter at a given sampling station

$\mathrm{S}_{\mathrm{n}}=$ Standard value of the $\mathrm{n}^{\text {th }}$ parameter

$\mathrm{V}_{\mathrm{io}}=$ Ideal value of the $\mathrm{n}^{\text {th }}$ parameter in pure water $(0$ for all parameters except $\mathrm{pH}$ and DO which are 7.0 and $14.6 \mathrm{mg} / \mathrm{L}$ respectively).

Unit weight was calculated by a value inversely proportional to the recommended standard value $S_{n}$ of the corresponding parameter.

$\mathrm{Wn}($ Unit weight $)=\mathrm{K} / \mathrm{Sn}$.

$\mathrm{W}_{\mathrm{n}}=$ Unit weight of the $\mathrm{n}^{\text {th }}$ parameter

$\mathrm{S}_{\mathrm{n}}=$ Standard value of the $\mathrm{n}^{\text {th }}$ parameter

$\mathrm{K}=$ Proportionality constant

The overall Water Quality Index was calculated by aggregating the quality rating with the unit weight linearly. Water Quality Index (WQI) $=\Sigma \mathrm{qnWn} / \Sigma \mathrm{Wn}$ 
TABLE 1: Categories the water quality index (WQI) with range of pollution.

\begin{tabular}{|c|c|c|}
\hline S. No. & WQI & Range of Pollution \\
\hline I & $<50$ & Slightly polluted \\
\hline II & $51-80$ & Moderately polluted \\
\hline III & $80-100$ & Excessively polluted \\
\hline IV & $>100$ & Severely polluted \\
\hline
\end{tabular}

In the present study, water samples were collected from three different locations of Dhamola river of Saharanpur in U.P. State. India, namely S-I (Muzaffrabad), S-II (Rakesh Cinema) and S-III (Tapri) for physico-chemical analysis. Water samples were collected from sampling sites during rainy season, winter season and summer season.

\section{Sampling Methodology}

From each sampling location, samples were collected during rainy season, winter season and summer season as recommended in WHO guidelines (WHO 2004, 2009). For statistical significance of the test results, each sampling location was sampled three times during rainy season, winter season and summer season. On a specific date, samples from all the three sampling locations were collected. In this way a total of 117 samples were collected and tested during this study. For physico-chemical analysis, water samples were collected in a one liter polyethylene (PET) bottle 15-20 $\mathrm{cm}$ below the water surface which was filled to the top to exclude air, analyzed within 24 hours and stored at $1-4^{0} \mathrm{c}$ temperature. Care must be taken not to catch any floating material or bed material into the container.

\section{Determination of water quality parameters}

For various physico-chemical study of river Dhamola the analysis of samples was done as per the method described in (APHA 1998). The instruments used were in the limit of précised accuracy. The chemicals used were of AR grade. Utmost care was taken during sampling to avoid any kind of contamination. $\mathrm{pH}$, dissolved oxygen and turbidity were measured at the time of sampling itself.

Table II- Seasonal Variation and Calculation of Water quality index in Rainy, Winter and Summer Season at different Sampling Sites

\begin{tabular}{|c|c|c|c|c|c|c|}
\hline Parameters & Seasons & S-I & S-II & S-III & $\begin{array}{l}\text { Standard } \\
\text { Value }\left(\mathbf{S}_{\mathrm{u}}\right)\end{array}$ & $\begin{array}{l}\text { Unit } \\
\text { Weight } \\
\left(W_{\mathrm{N}}\right)\end{array}$ \\
\hline \multirow[t]{3}{*}{$\mathrm{pH}$} & Rainy Season & 8.9 & 8.8 & 8.7 & \multirow{3}{*}{$6.5-8.5$} & \multirow{3}{*}{0.219} \\
\hline & Winter Season & 9.0 & 8.9 & 9.2 & & \\
\hline & Summer Season & 9.2 & 9.4 & 9.5 & & \\
\hline \multirow[t]{3}{*}{ Temperature ( $\mathrm{C}$ ) } & Rainy Season & 28.6 & 29.5 & 29.4 & \multirow{3}{*}{--} & \multirow{3}{*}{-} \\
\hline & Winter Season & 17.2 & 17.4 & 18.1 & & \\
\hline & Summer Season & 32.6 & 33.4 & 34.9 & & \\
\hline \multirow{3}{*}{$\begin{array}{l}\text { Turbidity } \\
\text { (NTU) }\end{array}$} & Rainy Season & 5.1 & 5.3 & 5.2 & \multirow{3}{*}{5.00} & \multirow{3}{*}{-} \\
\hline & Winter Season & 5.8 & 6.1 & 5.9 & & \\
\hline & Summer Season & 5.9 & 5.4 & 5.6 & & \\
\hline \multirow[t]{3}{*}{ Color } & Rainy Season & Clear & Clear & Clear & \multirow{3}{*}{--} & \multirow{3}{*}{-} \\
\hline & Winter Season & Black & Black & Black & & \\
\hline & Summer Season & Black & Black & Black & & \\
\hline \multirow{3}{*}{$\begin{array}{l}\text { TDS } \\
(\mathrm{mg} / \mathrm{L})\end{array}$} & Rainy Season & 498 & 505 & 509 & \multirow{3}{*}{500} & \multirow{3}{*}{0.0037} \\
\hline & Winter Season & 534 & 531 & 538 & & \\
\hline & Summer Season & 540 & 539 & 545 & & \\
\hline \multirow{3}{*}{$\begin{array}{l}\text { Calcium Hardness } \\
(\mathrm{mg} / \mathrm{L})\end{array}$} & Rainy Season & 74 & 76 & 75 & \multirow{3}{*}{75} & \multirow{3}{*}{0.025} \\
\hline & Winter Season & 80 & 79 & 81 & & \\
\hline & Summer Season & 79 & 81 & 86 & & \\
\hline \multirow{3}{*}{$\begin{array}{l}\text { Total Hardness } \\
(\mathrm{mg} / \mathrm{L})\end{array}$} & Rainy Season & 302 & 305 & 311 & \multirow{3}{*}{300} & \multirow{3}{*}{0.0062} \\
\hline & Winter Season & 346 & 349 & 361 & & \\
\hline & Summer Season & 335 & 370 & 381 & & \\
\hline \multirow{3}{*}{$\begin{array}{l}\text { Alkalinity } \\
(\mathrm{mg} / \mathrm{L})\end{array}$} & Rainy Season & 152 & 159 & 155 & \multirow{3}{*}{150} & \multirow{3}{*}{0.0155} \\
\hline & Winter Season & 160 & 176 & 182 & & \\
\hline & Summer Season & 163 & 169 & 191 & & \\
\hline & Rainy Season & 501 & 510 & 518 & & \\
\hline Solid & Winter Season & 589 & 563 & 588 & 500 & 0.0037 \\
\hline$(\mathrm{mg} / \mathrm{L})$ & Summer Season & 562 & 574 & 598 & & \\
\hline Magnesium & Rainy Season & 31 & 34 & 33 & & \\
\hline Hardness & Winter Season & 39 & 37 & 41 & 30 & 0.061 \\
\hline$(\mathrm{mg} / \mathrm{L})$ & Summer Season & 42 & 44 & 47 & & \\
\hline Chloride & Rainy Season & 248 & 255 & 251 & & \\
\hline$(\mathrm{mg} / \mathrm{L})$ & Winter Season & 276 & 278 & 290 & 250 & 0.0074 \\
\hline & Summer Season & 273 & 284 & 295 & & \\
\hline Dissolved Oxygen & Rainy Season & 5.1 & 5.2 & 5.1 & & \\
\hline$(\mathrm{mg} / \mathrm{L})$ & Winter Season & 5.7 & 6.4 & 6.1 & 5.00 & 0.3723 \\
\hline & Summer Season & 5.9 & 6.3 & 6.6 & & \\
\hline BOD & Rainy Season & 5.2 & 5.1 & 5.4 & & \\
\hline$(\mathrm{mg} / \mathrm{L})$ & Winter Season & 5.7 & 5.9 & 5.7 & 5.00 & 0.3723 \\
\hline & Summer Season & 5.3 & 5.4 & 5.6 & & \\
\hline WQI & Rainy Season & 102.67 & 103.8 & 105.1 & & \\
\hline & Winter Season & 114.72 & 122.1 & 118.7 & & \\
\hline & Summer Season & 113.67 & 118.7 & 124.2 & & \\
\hline
\end{tabular}


Figure 1: Seasonal changes in physico-chemical parameters with respect to WQI of Dhamola river during Rainy Season
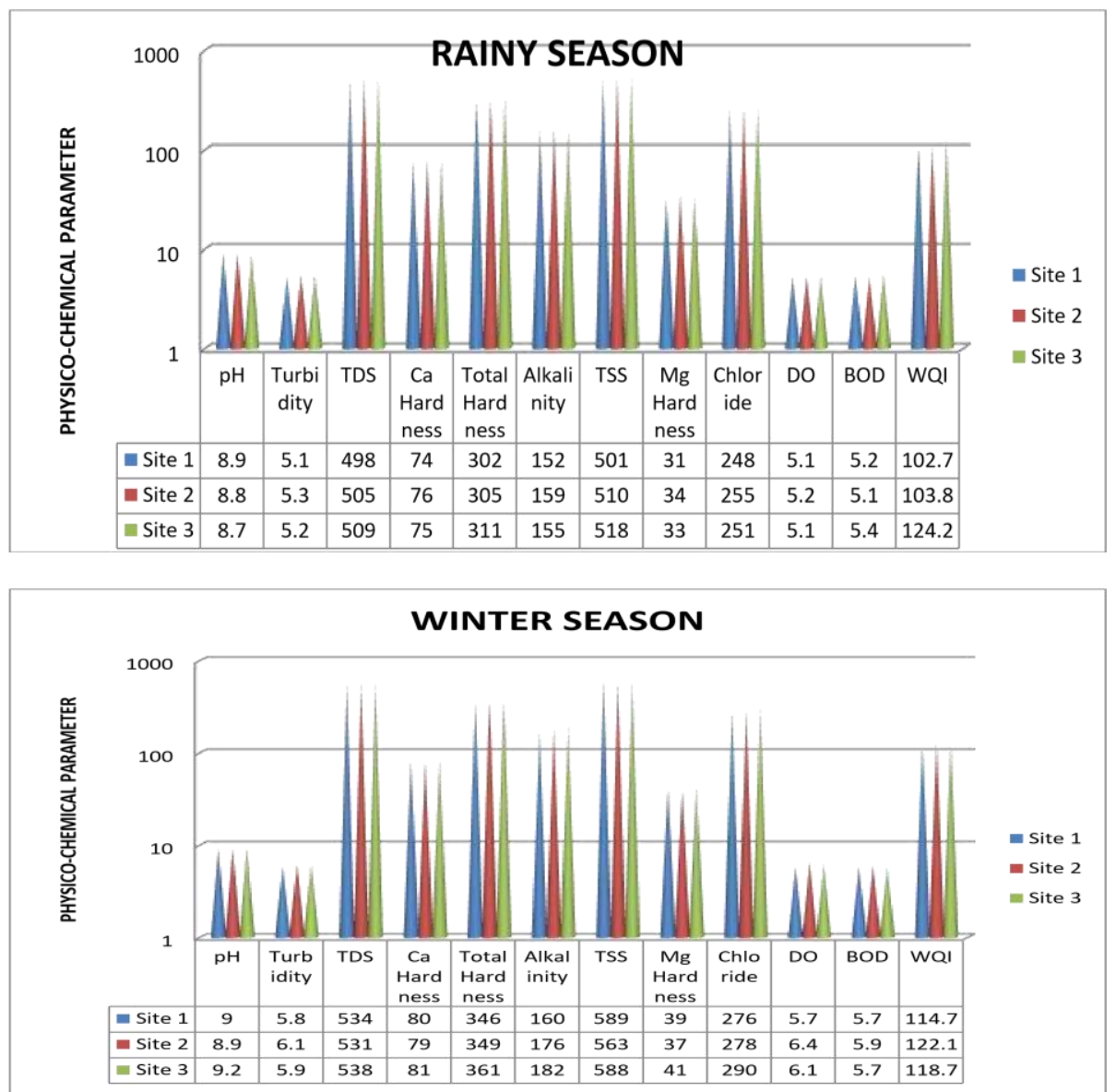

Figure 2: Seasonal changes in physico-chemical parameters with respect to WQI of Dhamola River during Winter Season

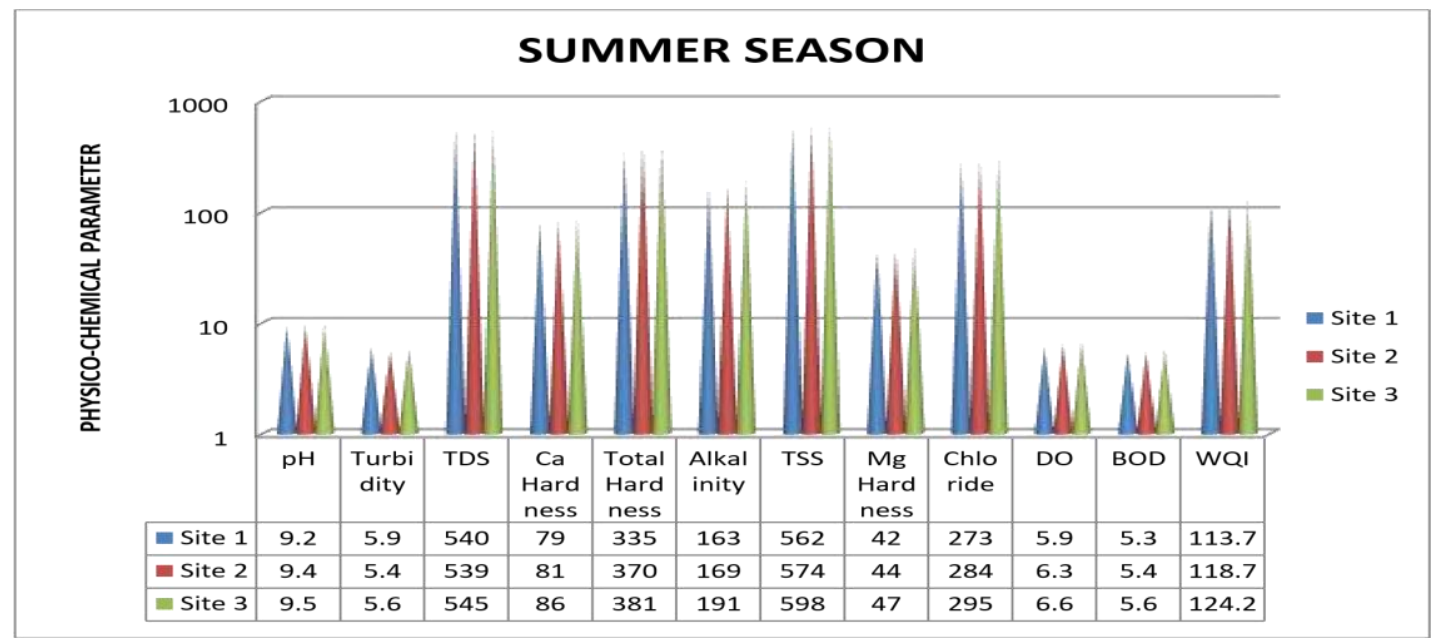

Figure 3: Seasonal changes in physico-chemical parameters with respect to WQI of Dhamola River during Summer Season

\section{Results and Discussion}

Water Quality Index of Dhamola River at three different sampling sites is established from various physicchemical parameters in different seasons. The values of various physic-chemical parameters for calculation of Water Quality Index are presented in table II.

The result shown that the $\mathrm{pH}$ values are alkaline in all three sites. The $\mathrm{pH}$ for Dhamola water varies from 8.7 to 8.9 in rainy season, 8.9 to 9.2 in winter season and 9.2 to 9.5 in summer season. The $\mathrm{pH}$ values during rainy, winter and summer season are greater than 8.7 at all sampling sites.

During the investigation period temperature varied from $17.2^{\circ} \mathrm{C}$ to $34.9^{\circ} \mathrm{C}$. The temperature showed an upward trend from winter to summer season followed by downward trend from monsoon season onwards.

Turbidity of water is actually the expression of optical property (Tyndall effect) in which the light is scattered by the particles present in the water. The seasonal average values of Turbidity in all three sampling stations varies from 5.1 to 
5.3 NTU in rainy season, 5.8 to $6.1 \mathrm{NTU}$ in winter season and 5.4 to $5.9 \mathrm{mg} / \mathrm{L}$ in summer season in which maximum value was found during winter season.

Total Dissolved Solids (TDS) create an imbalance due to increased turbidity and cause suffocation to the fish life even in the presence of high dissolved oxygen. The TDS value in wastewater varies from 498 to $509 \mathrm{mg} / \mathrm{L}$ in rainy season, 531 to $538 \mathrm{mg} / \mathrm{L}$ in winter season and 539 to $545 \mathrm{mg} / \mathrm{L}$ in summer season. Maximum value of TDS was observed in the wastewater of Tapri which contains mixture of different kind of wastes from different operations of paper industries.

Calcium, magnesium, alkalinity and chloride ion concentrations showed clear seasonal variation, with maxima in summer months and minima in rainy season at almost all the sites. This seasonal variation suggests that river water chemistry is influenced by annual cycles with biological and geological breakdown in the summer season leading to the accumulation of chemicals during dry periods, followed by dilution of those chemicals by monsoonal rainfall. The total hardness is mainly due to $\mathrm{Ca}, \mathrm{Mg}$ and Eutrophication (Sharma 2001, De 1994). The water containing excess hardness is not desirable for potable water as it forms scales on water heater and utensils when used for cooking and consume more soap during washing of clothes.

The dissolved oxygen content at all sites was (> $5.0 \mathrm{mg} / \mathrm{L})$ throughout the year. The abrupt rise in BOD values at all sites is attributed due to the discharge of paper mill effluent from Star Paper Mill, municipal effluent, addition of sewage coming through sewerage pipes and untreated or inadequately treated effluent discharged from several types of industrial units. It may be stated that the maximum value of BOD for potable water is $2 \mathrm{mg} / \mathrm{L}$ and that for bathing it is $3 \mathrm{mg} / \mathrm{L}$. The higher values of BOD observed at all sites indicate a high degree of organic pollution, rendering the water unsuitable even for bathing purposes throughout the year.

\section{Conclusion:}

The point sources contributing to river Dhamola have very high organic pollution, deteriorating water quality of the river Dhamola. The summer, monsoon and winter seasons showed different level of seasonal fluctuations in various physicochemical parameters and Water Quality Index. The major sources of pollutants are local anthropogenic activities, open domestic sewage, sewage coming through sewerage pipes, agricultural runoff containing fertilizers, pesticides, insecticides and industrial effluent containing toxic chemicals in higher amount. Further, untreated and/or partially treated waste an input of municipal and industrial effluents adds the pollution in the river as assessed by water quality index. It is recommended that either all the point sources should be treated before discharging their wastes into river Dhamola It can, therefore, be concluded that river water is not suitable for drinking and irrigation purposes without any form of treatment, so possible remedial methods should be adopted for this water resource for improving its quality. It is very much necessary to conduct more research on this river.

\section{Recommendations:}

1. It is recommended that the wastewater generated by the municipal areas of Saharanpur,be treated and utilized for irrigation through an organized network.

2. The industrial units discharging their effluents directly into the river without any treatment should install effluent treatment plants.

3. Sewerage disposal of internal city will also be linked with the main sewerage pipeline for final disposal and treated before its final disposed into the river.

4. Pounding of wastewater in the streets be avoided through effective wastewater collection system.

\section{References}

[1].Agarwal A, Saxena M Assessment of pollution by physicochemical water parameters. Advanced applied science research 2011; 2 (2): 185-189.

[2].APHA. Standard methods for the examination of water and waste water, American Public Health Association, Washington, America. 1989.

[3].APHA. Standard methods for the examination of water and waste water', AWWA and WPCF Washington, America. $1998 ; 20$.

[4].BK Sharma. Industrial Chemistry, Goel publishing house Meerut, India. 2001.

[5].Collins MA. and Jenkins A The impact of agricultural land use on stream chemistry in the middle hills of the Himalayas, Nepal. J. Hydrol 1996; 185: 71-86.

[6].De AK. Environment chemistry (III edu), New Delhi, India. 1994.

[7].Gupta RC., Gupta AK and Shrivastava RK "Assessment of water quality status of holy river Kshipra using water quality index", J. Indian Water Resources Society 2012; 32(1-2): 33-39.

[8].ISI. Indian Standard specification for drinking water, IS10500, ISI, New Delhi, India. 1983.

[9].Jenkins A, Sloan WT and Cosby BJ Stream chemistry in the middle hills and high mountains of the Himalayas, Nepal. J. Hydrol 1995; 166: 61-79.

[10]. Kumar A. Water Pollution. Nisha Enterprises New Delhi, India. 2004; 1-331.

[11]. Malik Dinkar. Assessment of water quality at Paon Dhoi river during monsoon and after season, saharanpur (U.P.). Int. J. Phy. \& App. Sci. 2015;5(3): 92-102.

[12]. Naik S and Purohit KM. "Studies on water quality of river Brahmani in Sundargarh district, Orissa", Indian J. Environmental and Eco-planning 2001; 5(2): 397-402.

[13]. Sharma MP, Patra, S and Singal, SK. Water quality management of Damodar river, J. Indian Water Resources Society 2009; 29(2): 23-31. 
[14]. Shivaraju HP. Impact assessment of sewage discharge on underground water qualities around municipal sewage treatment plant. International Journal of Research in chemistry and Environment. 2011; (1) : 124-130.

[15]. Singh DF. "Studies on the water quality index of some major rivers of Pune, Maharashtra", Proceedings of the Academy of Environmental Biology 1992; 1(1): 61-66.

[16]. Tiwari TN, Mishra M. A preliminary assignment of water quality index of major Indian rivers, IJEP. 1985; 5: 276279.

[17]. W.H.O. Guidelines for drinking water quality, Vol.1, Recommendations WHO, Geneva, Switzerland. 1984.

[18]. WHO. Calcium and Magnesium in Drinking-water: Public health significance, Geneva, Switzerland. $2009 ; 276$.

[19]. WHO. Guidelines for drinking water. Second Edition WHO, Geneva, Switzerland. 2004; 224-230. 